\title{
Lusotopie
}

Recherches politiques internationales sur les espaces

issus de l'histoire et de la colonisation portugaises

$\mathrm{XV}(2) \mid 2008$

Histoires d'Asie

\section{Local Power in Colonial and Contemporary Goa}

Pouvoir local à Goa colonial et contemporain

Poder local na Goa colonial e contemporânea

\section{Aureliano Fernandes}

\section{(2) OpenEdition \\ Journals}

Electronic version

URL: http://journals.openedition.org/lusotopie/1557

ISSN: $1768-3084$

Publisher:

Association des rechercheurs de la revue Lusotopie, Brill, Karthala

Printed version

Date of publication: 20 November 2008

Number of pages: 151-173

ISSN: 1257-0273

Electronic reference

Aureliano Fernandes, «Local Power in Colonial and Contemporary Goa », Lusotopie [Online], XV

(2) | 2008, Online since 01 February 2016, connection on 19 April 2019. URL : http://

journals.openedition.org/lusotopie/1557 


\section{LOGAL POWER IN GOLONIAL AND GONTEMPORARY GOA}

Provincial governments, whether "colonial non-democratic" or "post-colonial democratic", perceive local government as appendage to "Empire of the State", despite support and legitimization for the latter from "Colonial Federal Regime" and later "Post-Colonial Democratic Federal Regime". In fact, in the Indian state of Goa, local governments were more empowered substantively under the Portuguese colonial regime, than under present day democratic regime, even though the former were partially elective institutions with limited franchise. The article also maps the shortcomings of urban local government viz its racial bias in appointment to posts, prevalent corruption due to privileges bestowed on municipal officers and the virtual stagnation of local government institutions under the continental Portuguese colonial regime, unlike the evolution of democratic local government in the rest of India under the British.

Besides the state created local institutions, this article focuses on colonial state's assimilation of traditional associative communitarian institution. In contrast to this, it is argued that unscrupulous post-colonial governments have, under the guise of law and "public interest", virtually annihilated these associative institutions by depriving them of their most precious resource - land. In the postcolonial phase, local governments have been intentionally kept financially dependent on provincial governments. It is evident that in the wake of over $50 \%$ urbanisation of Goa and rapid migration of people from the rural to urban areas and to Goa from other parts of India, local governments are ill-equipped deal with the complexities of spatial planning, water, and resource allocation and management due to large scale political interference from provincial governments and parties and their own shortcomings.

\section{Pouvoir local à Goa, coloniale et contemporaine}

Les gouvernements provinciaux, qu'ils soient «coloniaux et non démocratiques » ou "postcoloniaux et démocratiques », perçoivent le gouvernement local comme un prolongement de «l'Empire de l'État», malgré le soutien et la légitimation de ce dernier par le «Régime fédéral colonial» et plus tard par le «Régime démocratique fédéral postcolonial». De fait, dans l'État indien de Goa, les gouvernements locaux jouissaient de pouvoirs sensiblement plus importants sous le régime colonial portugais que sous le régime démocratique existant de nos jours, même si autrefois, ces institutions n'étaient que partiellement électives, avec un droit de vote limité. Cet article illustre également les carences du gouvernement local urbain, c'est-à-dire ses préjugés raciaux pour l'attribution de certains postes, sa corruption généralisée due aux privilèges accordés aux fonctionnaires municipaux et la quasi-stagnation des institutions du gouvernement local sous le régime colonial portugais continental, qui contraste avec l'évolution du gouvernement local démocratique dans le reste de l'Inde sous la domination britannique.

En dehors des institutions locales créées par l'État, cet article s'intéresse à l'assimilation par l'État colonial des institutions communautaires associatives traditionnelles. Par contraste avec ce thème, d'aucuns avancent l'idée que des gouvernements postcoloniaux sans scrupules ont, sous couvert de la loi et de «l'intérêt public », pratiquement annihilé ces institutions associatives en les privant 
de leur ressource la plus précieuse : la terre. Au cours de la période postcoloniale, la dépendance financière des gouvernements locaux par rapport aux gouvernements de province a été volontairement maintenue. Il est évident que, dans le sillage de l'urbanisation de plus de $50 \%$ de Goa et de la migration rapide des habitants des zones rurales vers les zones urbaines, ou des autres régions de l'Inde vers Goa, les gouvernements locaux sont mal équipés pour maitriser les complexités de l'aménagement de l'espace, de la distribution et de la gestion de l'eau et des ressources, en raison d'interférences politiques sur une large échelle de la part de tierces parties et des gouvernements de provinces et à cause de leurs propres carences.

\section{Poder local na Goa colonial e contemporânea}

Os governos provinciais, quer "coloniais não-democráticos" ou "pós-coloniais democráticos", encaram os governos locais como um apêndice do "Império do Estado", apesar do apoio e da legitimação para estes últimos pelo "Regime Colonial Federal" e o posterior "Regime Pós-colonial Democrático Federal". De facto, no Estado Indiano de Goa, os governos locais tinham substancialmente mais poder sob o regime colonial português que sob o actual regime democrático, mesmo apesar dos primeiros serem instituições parcialmente electivas com direitos políticos limitados. O artigo também faz o levantamento das lacunas dos governos locais urbanos através dos preconceitos raciais nas nomeações para os cargos, a corrupção predominante devido a privilégios concedidos aos funcionários municipais e a estagnação virtual das instituições governamentais locais sob o regime colonial e continental português, ao contrário da evolução dos governos democráticos locais no resto da Índia sob o domínio britânico.

Além do estado criado pelas instituições locais, este artigo foca a assimilação pelo estado colonial das instituições associativas e comunitárias tradicionais. Argumenta-se, em oposição a isto, que os governos pós-coloniais aniquilaram praticamente, sob a capa da lei e do "interesse público", estas instituições associativas ao privá-las do seu recurso mais precioso - a terra. Na fase pós-colonial, os governos locais ficaram dependentes, de maneira intencional, dos governos provinciais. É evidente que, com o resultado da urbanização de mais de $50 \%$ de Goa e a migração rápida das populações das áreas rurais para as áreas urbanas e para Goa a partir de outras partes da Índia, os governos locais estão mal preparados para lidar com as complexidades do planeamento espacial, o abastecimento de água e a distribuição e gestão de recursos devido à intervenção política em grande escala dos governos provinciais e dos partidos e as suas próprias lacunas.

$\mathrm{T}$ he central argument of this article, based on the working of institutionalised local government ${ }^{1}$, suggests that Provincial governments, whether "colonial non-democratic" or "post-colonial democratic", perceive local government as

1 I have used "institutionalised local government" to mean "state created local government institutions" and "associative institutions" to mean "traditional local institutions of governance" which emerged from civil society. "Non elective institutional structure" refers to bureaucracy or civil service structure at sub state level. "Colonial Federal Government" refers to the Colonial Government in Lisbon and "Post-colonial Federal Government" refers to the Government of India. 
appendage to "Empire of the State", despite support and legitimization for the latter from "Colonial Federal Regime" and later "Post-Colonial Democratic Federal Regime". These provincial governments are solely engaged with protecting their power rather than negotiating its suggested devolution to lower levels of government, by Federal governments. In fact, analysis shows that in the Indian state of Goa, local governments were more empowered substantively under the Portuguese colonial regime, than under present day democratic regime, even though the former were partially elective institutions with limited franchise.

This argument is articulated by tracing the historical evolution of both colonial and post-colonial local governments in their urban and rural dimensions, also underlining their formal and functional nuances. It is seen that despite the criticality of urban local government towards entrenchment and perpetuation of Portuguese empire by even funding of military expeditions in the colonial phase, the provincial colonial government called for curbing of their powers and privileges, especially the latter's privilege of direct access to the King which was used by the urban government to complain of excesses of the Viceroys in Goa.

The article also maps the shortcomings of urban local government viz its racial bias in appointment to posts, prevalent corruption due to privileges bestowed on municipal officers and the virtual stagnation of local government institutions under the continental Portuguese colonial regime, unlike the evolution of democratic local government in the rest of India under the British.

Besides the state created local institutions, this article focuses on colonial state's assimilation of traditional associative communitarian institution - the Gaunkari which originated in antiquity but was largely multicultural and had strong elements of direct democracy. This institution, it is argued, was so well advanced in social, political and economic governance, that the colonial state did not find it exigent to establish rural local institutions in Goa. The erroneous imposition of European continental land ownership law has been acknowledged as the most significant reason for imposition of taxes on first peoples (Gaunkaris) and their institutions but the sensitivity of the colonial rulers in withdrawing this tax is also acknowledged. The machinations of colonial state control over associative institutions have also been mapped. In contrast to this it is argued that unscrupulous postcolonial governments have, under the guise of law and "public interest", virtually annihilated these associative institutions by depriving them of their most precious resource - land.

In the post-colonial phase, which began with Goa's Liberation ${ }^{3}$, it is argued that the intransigence of provincial governments to devolve administrative and financial powers despite a constitutional amendment by Federal Government ${ }^{4}$, in

2 The coinage "Empire of the State" connotes an unresponsive, unaccountable, highly centralized, bureaucratized, non transparent, patriarchal state and non democratic state, typical of the age of Empires, which may have been characteristic of the colonial era but is not extinct in contemporary democracies in its substance.

3 Goa was freed from Portuguese Colonial rule by the Indian Army on 19 December 1961, in Operation Vijay. The Portuguese Army surrendered. This event is referred to as Liberation of Goa. Goa was incorporated as a Union Territory, i.e. administered by the Central Government till it became an autonomous province (commonly refered to as a state in India), in 1987.

4 Although the Constitution of India refers to Union of India, India is a two-tier federation 
1993, emanates from power compulsions of provincial governments of small provinces, since they fear a threat to their own power and functional base due to the small geographical size of $\mathrm{Goa}^{5}$. Local governments have been intentionally kept financially dependent on provincial governments, thus inhibiting their autonomy and their ability to transform the lives of their people.

Likewise, post-colonial urban governments have been dysfunctional due to lack of administrative and financial devolution by provincial government and despite the Federal Government empowerment of this level of government through the 74th Constitutional amendment. Participatory planning through involvement of rural and urban governments and district planning committee though mandated by law is not a reality. It is evident that in the wake of over $50 \%$ urbanisation of Goa and rapid migration of people from the rural to urban areas and to Goa from other parts of India, local governments are ill-equipped deal with the complexities of spatial planning, water, and resource allocation and management due to large scale political interference from provincial governments and parties and their own shortcomings.

The article concludes by articulating the need for synergy between institutionalised local power and associative power and shedding of conflicting notion of power held by small provincial governments such as those of Goa, in favour of the notion of subsidiarity at sub state levels. This is essential for transformation and empowerment of local institutions and deepening of democracy and strategising a better quality of life for people served by local governments.

\section{Evolving structure of local governments in Goa}

The Portuguese colonial dispensation can be credited with the establishment of the first municipal government in Asia, the Senado de Goa, at their capital Old Goa, as early as 1511, just a year after the conquest of the island of Ilhas, Goa. As the Portuguese conquered the coastal talukas ${ }^{6}$ of Bardez, Mormugao and Salcete by the 16th century and the hinterland talukas of Pernem, Sattari, Bicholim, Ponda, Sanguem, Canacona and the overland territories of Daman and Diu to complete the conquest of Goa by the 18th century, urban bodies under various nomenclatures such as Câmara Municipal/Comarcas Municipalities/Municipal Committee and Câmara Geral were extended to the taluka capitals.

with a strong central government or Centre and 28 provincial governments and 7 Union Territories administered by the Centre. From 1993, India became a three-tier federation with legitimisation of local governments. But local government is a provincial subject as per the division of powers between the Federal and Provincial governments, and hence it depends on the latter to devolve powers to local governments.

${ }^{5}$ Goa is geographically the smallest state in India with a total area of 3,701 square kilometers. It is $1 / 12$ the size of the neighboring Indian state of Maharashtra and would form just on taluka (subdivision) of that state.

${ }_{6}^{6}$ Taluka is a subdivision of a province/state below which is the block (group of villages) and at the lowest level is the village, which is further divided into wards. 
Tabl. I. - Glassifying local power in GoA

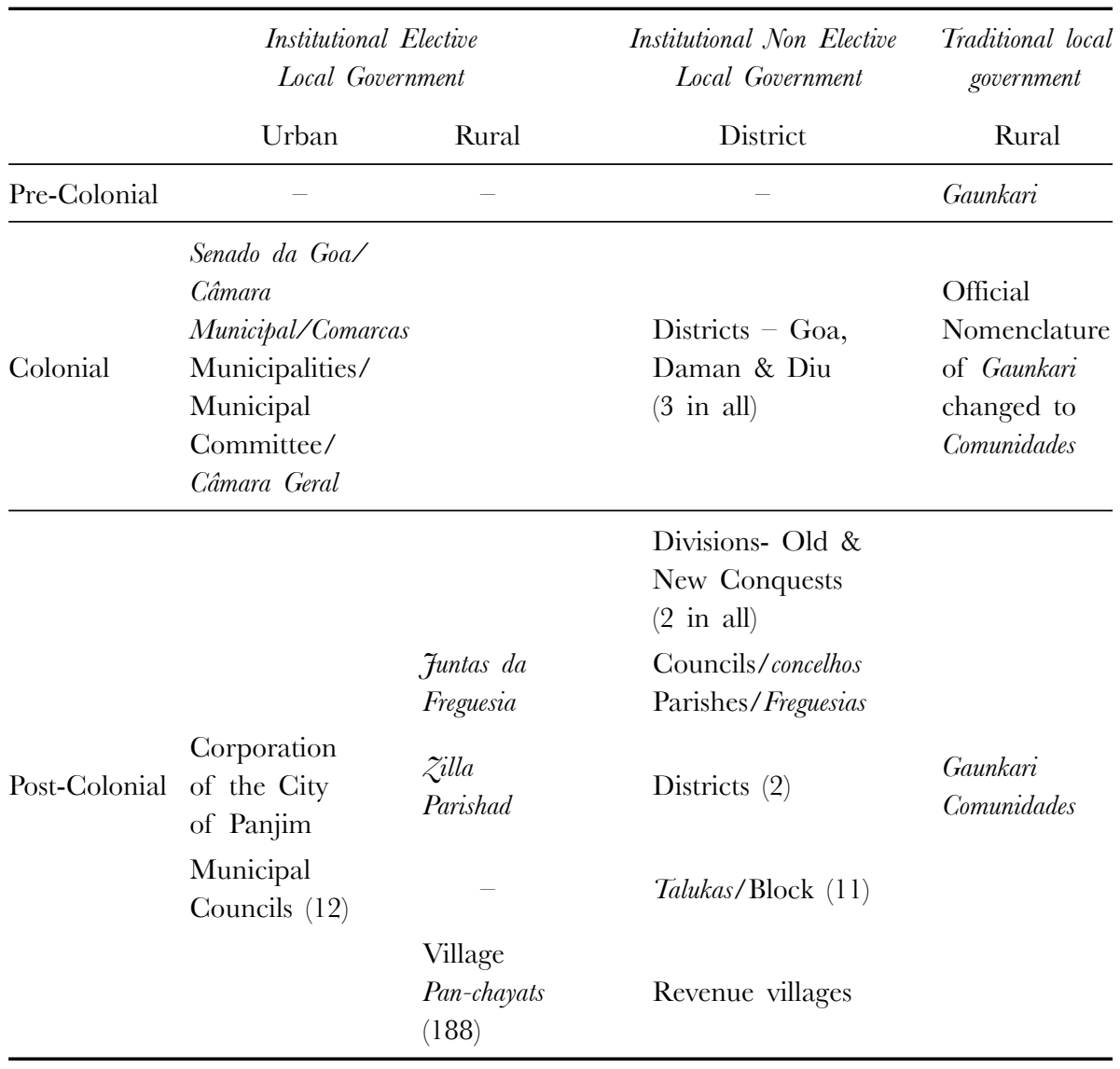

Sources: compiled from various sources.

The Portuguese however did not find it exigent to have rural institutionalized local government, the Funtas de Freguesia, until 1959, just about two years before their departure from Goa, due to the existence of traditional advanced system of associative governance called Gaunkari or Comunidade, which regulated social and economic life and even administered justice. The revenue and law and order administration at the sub state level consisted of three districts viz. Goa, and overland territories of Daman and Diu, located near Indian state of Gujarat. The District of Goa which later became the capital of the Portuguese Empire in the East was divided into two divisions viz. Velhas Conquistas (coastal talukas captured by 16th century) and Novas Conquistas (hinterland talukas captured by 18th century). Each division was sub-divided into concelhos, 13 in all, including two at Daman and one at Diu. The concelhos were divided into Parishes or Freguesias at the village level, as seen in table 1 above.

In the post-colonial phase, the Portuguese system of administration and local government was replaced by the British system which was in existence at the all India level. Portuguese Municipal Act continued into the democratic framework 
in Goa for nearly 7 years, despite Liberation of Goa from the Portuguese rule, in 1961. Thereafter, in 1968, there was an abrupt implantation of the British colonial urban government as it evolved in India. Within the two tier Indian federal structure of "modern state", Municipal Councils and Panchayati Raj institutions, functioned as extensions of provincial governments, merely executing function on behalf of government departments with negligible autonomy and powers, till they were allocated planning, finances and autonomy under the 73rd and 74th Constitutional Amendments in 1993. Traditional local power continues to be agglomerated in the Gaunkari or Comunidade system with the provincial government having appointed an administrator to regulate their affairs as was done by the Portuguese.

\section{Institutionalised urban local power under the colonial state}

Urban government was coextensive with the expansion of Portuguese empire in Goa. It originated with the establishment of the first municipality called Senado de Goa, by Afonso de Albuquerque, at the Portuguese capital city of Old Goa. The intent was not only to manage civic affairs of Ilhas (now Tiswadi taluka), where the Portuguese had first settled, but to entrench and perpetuate the Portuguese Empire firmly in the East, by bestowing municipal offices as dowry ${ }^{7}$ and assigning them to selected gentlemen with sufficient aptitude from among the married settlers to act as aldermen, market inspectors, justices of peace, police constables and so on. In the 16th century, it spread to Salcete in the South and Bardez in the North, with the establishment of Senados da Comarca in 1784. Urban Government was discontinued in 1778, reestablished in 1783 and later substituted by Comarcas Municipalities.

By the 19th century each taluka (concelho) capital had a municipality ${ }^{8}$. So there were 10 municipalities in Goa, two in the overland pockets of Daman and one in Diu which bordered the North Western Indian state of Gujarat. In Daman, the Câmara de Damao with privileges akin to Evora, which existed since 1613, was substituted by Câmara Municipal de Damao in 1834. A senate was established in Diu in 1603, and elevated to Câmara in 1835 (Gune 1979: 16).

In terms of structure and functions, the Senado de Goa, was structured on the Municipality of Lisbon model, including its election procedures and functions of councilors, though not followed in toto. Appointments to the posts of city captain, head constable and factory clerk were reserved for men sent by the (Portuguese) King, while aldermen, justices of peace and city attorney were elected through a complex system of balloting. Besides four representatives of the artisans were elected by the House of Twenty Four, an artisans'guild. The colonial, theocratic and racial underpinnings of empire were evident in the municipal administration, since all the offices which had decision making powers were given to married Christian Portuguese.

${ }^{7}$ Dowry, roughly translated refers to the practice of offering or demanding money to the groom on marriage of one's daughter.

${ }^{8}$ Municipalities were established in Pernem, Sanquelim and Ponda, in North Goa in 1880. In Sanguem, Municipal committee replaced Câmaras Agrárias in1880, and in Quepem, in South Goa, the municipal committee established in 1880, replaced the Camara Geral of 1849. 


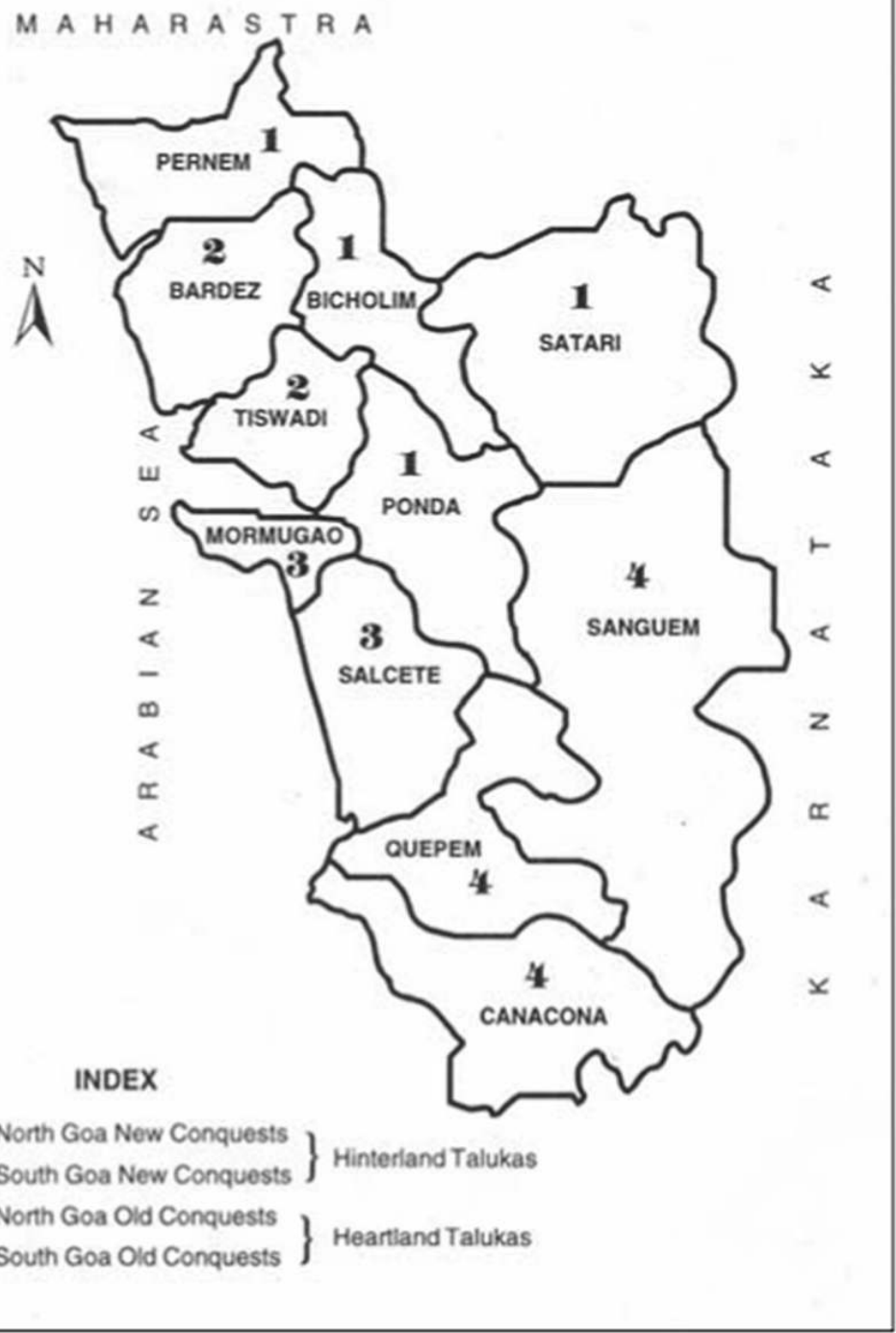

Fig. 1. Map of Goa showing Portuguese Divisions of Old \& New Conquests \& Concelhos

Elections to municipal offices were held every three years, in December and were centrally conducted by an impartial authority, the Crown Judge of the city (corregedor da comarca or ouvidor geral) by summoning all citizens and choosing six from among them. Three lists of the candidates for various city posts were then scrutinised by the Viceroy, who sometimes added his own list of names and decided who would serve in each year. 
The municipal officials were given a special charter of privileges by Albuquerque, and accented to by the Crown, under which there was no appeal against the judgment of market inspectors beyond the municipal board. The Casados (married Portuguese) were immune from being imprisoned in public jails while in office. They could navigate freely, were exempted from taxes and loan demands by state authorities. They could also sell movable or immovable property received from the state as dowry, if they wished, provided buyers were not Muslims or Hindus.

\section{Tabl. II. - Types of OFfices IN MUNicipalities in Goa under Colonial Rule}

\begin{tabular}{|c|c|c|c|}
\hline $\begin{array}{l}\mathcal{N}^{\circ} \text { of } \\
\text { posts }\end{array}$ & Types of offices & Nature of office & Frequency of election \\
\hline 1 & City captain & Ex officio nominated by Crown & - \\
\hline 3 & Aldermen (vereadores) & Elected & Three years \\
\hline 2 & $\begin{array}{l}\text { Justices of Peace } \\
\text { (juizes ordinaries) }\end{array}$ & Elected & Three years \\
\hline 1 & $\begin{array}{l}\text { City attorney (procurador } \\
\text { da cidade) }\end{array}$ & Elected & Three years \\
\hline \multirow[t]{4}{*}{4} & $\begin{array}{l}\text { Representatives of artisans } \\
\text { (procuradores dos mesteres) }\end{array}$ & $\begin{array}{l}\text { Elected by artisans guild } \\
\text { called Casa dos Vinte Quatro }\end{array}$ & Three years \\
\hline & $\begin{array}{l}\text { Market Inspectors } \\
\text { Police Constables }\end{array}$ & Elected & Three years \\
\hline & Head constable & Nominated by Crown & - \\
\hline & Factory clerk & Nominated by Crown & - \\
\hline
\end{tabular}

Sources: compiled from various sources.

The relationship between the provincial colonial government and the municipality especially that of Old Goa was conflictive, though at times they were forced to cooperate for their own survival. This conflict intensified post 1530, when Goa became the headquarters of entire Portuguese India, which extended from East Africa to the Far East, as restrictions were placed on councilors'privileges. The privileges of immunity from imprisonment in public jails were retained, but city elders'exclusive judicial control over those appointed by them to the municipality, ceased and they could approach the state judiciary for redress.

In comprehending the relationship between the urban government and colonial State, it is exigent to understand the structure of the colonial state. The state administration which underwent periodic changes contingent on events in Portugal, consisted of a Viceroy/Governor General, assisted by the Secretary General (Secretário Geral) of India. The Council of State (Conselho do Estado) and the Council of Three Estates (Conselho dos Três Estados) the former influenced by the power of the Viceroy.

To ensure autonomy, the City captain, an agent of the Viceroy, had to swear to protect the privileges of the councilors and contribute towards smooth administration. Nonetheless, in the 17th century, his office was resented by the councilors, for hindering effective administration and for acting as the Viceroy's agent and disclosing matters discussed in the council and secret correspondence sent to the Crown regarding state administration (DeSouza 1979). 
In terms of functional autonomy from the state, the municipality controlled the markets, maintained city drainage, streets, water supply, city walls and defences. Financial autonomy emanated from house and property taxes collection, lease of shops and lands, fines, and licenses issued to artisans, shopkeepers and other professionals from the city. In the 16 th and 17 th centuries, the municipality at Old Goa even supported the Colonial Empire by incurring defence related expenditure by building city walls, galleys, and giving loans to the state for military expenditure (Ibid.: 141-143). The Goa municipality had privileged immunity from state audit and resented interference by the state in account keeping, which provided scope for corruption.

In the 17 th century, the power struggle between the municipality and state continued, especially in the economic and social arena. The Casados agreed to state imposed custom levies, provided, municipality was the collecting agency. The concessions they extracted from the state opened out new avenues for employment and profiteering, to the dismay of Viceroys, who complained to the King about municipality officials hoarding grain in times of scarcity for profiteering. To appease the state, the municipality retained unjustified taxes on the people, such as collecta $\operatorname{tax}^{9}$, despite the ceasing of Dutch attacks. When the state appropriated the tax, the municipality began a vilification campaign against state's inefficiency in its correspondence with the King, till the revenue was restored to them. The municipality also engaged with welfare and humanitarian functions such as caring for refugees of Portuguese defeats in Ceylon and Kanara, provision of shelter for orphan girls and women gone astray and funding of the monastery of Santa Monica, for daughters of impoverished Portuguese who could not afford to marry them off by paying dowries, brought near bankruptcy by the end of 17 th century (Desouza 1979).

The principal cause of conflict between the state and municipality was the latter's power to directly correspond with the Crown annually, informing him about the affairs of state, and power to send their Attorneys to the royal court in Portugal. The Crown encouraged this practice in order to keep in check the vast powers granted to the Viceroys in India. In 1630, the Count of Linhares, called upon the Crown to suppress the municipalities if the Portuguese empire in India was to be saved from total collapse. It had obvious reference to the powers which the municipalities enjoyed of directly complaining to the king about the functioning of the state government. The Crown suggested moderation to both Viceroys/Governors, and to councilors, advising the former to check abuse and corruption, and the latter to approach the Viceroy and resolve their grievances, since he was the Crown's representative in India (Desouza 1979).

To the credit of the municipality, it must be said, that although at conflict with the colonial government, the municipality held together the Portuguese empire in Goa and provided continuity, while the Viceroys changed every three years. The municipality helped the consolidation of empire by funding military and naval campaigns. It was an autonomous institution and not merely a rubber stamp of the Viceroys, according to G.R. Boxer (1980). 


\section{Non elective rural power under the colonial state}

Although, the Constitutional regime (1836-1910) in Portugal was intent on administrative reform in Portugal and its colonies, the Code of 1881, which promulgated administrative decentralization was considered incompatible for India, thus reverting it to governance under the Code of 1869. The non elective institutional structure consisted of 3 districts - Goa (with a Governor General) and Daman and Diu (with a Governor). The district of Goa was divided into two divisions - Velhas Conquistas (Old Conquests) and Novas Conquistas (New Conquests) ${ }^{10}$.

The Old Conquests were organised into three concelhos da administração (councils of administration). Concelhos were further divided into Freguesias (Parishes) or Regedorias, 98 in all. Every concelho was placed under an Administrador (Administrator) cum head of the taluka municipality, appointed by the Governor General. Every Freguesia had a minor council called Funta Local, (Local Council of Freguesia), headed by a magistrate called Regedor, who oversaw administration and police. These three units came into being from 1837 when the constitutional regime began functioning properly (Gomes 2004).

Administratively, the Hindu majority New Conquest talukas (concelhos), comprising six concelhos differed from the Old Conquests and were headed by Intendente Geral who was the chief administrator, and whose position was that of High Court Judge with wide magisterial, judicial and administrative powers. The overseas districts - Daman and Diu geographically linked to the Indian state of Gujarat, were divided into three concelhos as follows - Daman, divided two concelhos (Daman and Nagar Havely), and the district of Diu comprised one concelho.

Two enactments (the 1911 Constitution of Republic and the 1917 Carta Orgânica do Estado da India) gave the power of decentralisation and autonomy to Portuguese India ${ }^{11}$. However, the frequent changes in government did not help the cause of decentralisation since the dictatorial regime of Sidonio Pais in Portugal suspended all such efforts. It was again restored in 1919. The local government structure remained unchanged except for the addition of two more concelhos in Goa, raising the total number of concelhos in Goa. Daman and Diu to 14. Later, under the Dictatorship of Oliveira Salazar too, despite administrative changes at the provincial level, due to the enactment of Carta Orgânica do Estado da India of 1926, the Colonial Act of 1930 and the renaming of Goa from "colony" to "Overseas Province » by the Colonial Act of 1951, to bypass the United Nations directive of ceding all colonies, local administration remained unchanged.

The Portuguese, unlike the British, did not contribute much to the development of local rural government in its colony. It simply did not fit into the Empire's colonial scheme. Hence only basic functions of law and order and tax collection were managed by rural administration.

${ }^{10}$ Goa was not captured in its entirety by the Portuguese. They initially wrested only the city of Old Goa in 1510. The Old conquests (comprising the present talukas of Tiswadi, Bardez, in the North and Salcete and Mormugao in the South) were captured by 16th Century. The New Conquests (essentially comprising Pernem, Sattari, Bicholim, in the North, Ponda in the East and Sanguem, Quepem and Canacona Talukas in the South) came under the Portuguese as late as the 18th Century.

${ }^{11}$ In some cases, the Metropolitan administrative Code of 1896 applied pending preparation of a Provincial Code. 


\section{Associative rural local power under colonial and post-colonial state: the Gaunkari system}

In the Lusotopic space of Goa, local associative power, which essentially refers to indigenous community institutions, originated in the form of the Gaunkari System (also called Gaunkarias or Comunidades) ${ }^{12}$, which were village republics of the first settlers or first peoples' in Goa, traced to the beginning of the Christian era. These republics, essentially aggregates of a plurality of families (known as vangods, vangads, or vangors), were descendant from a common genealogy, under the command of one leader, who owned land by absolute communion, settled across the terrain of Goa.

Pre-dating the Portuguese and similar to Bratskiyes of the Mongols, Russian Mirs and Greek City States (Gomes Pereira 1981: 2) the Gaunkaris, had contractual welfare responsibility towards their members. They could not indulge in trade, business or any profiteering activity. The institutional rubrics mandated them to bring large tracts of land under cultivation, establish irrigation networks, reserve land for grazing, places of worship, community health centres, and places for shelter for the needy (Pereira 2000). The land and assets of the Gaunkaris belong to the Gaunkars (male descendants of the first settlers). The revenue surplus was channelised towards social welfare and annual dividends were paid to members, as prescribed by the Code of Comunidades.

The Gaunkari system had a two tier structure - the Acordado (Managing Committee), which had a three year tenure, and the General Body, which could overrule decisions of the former. The Managing Committee which had one or more elected representatives from each vangod, initially took decisions through unanimity, but changed to majority vote due to serious drawbacks of the veto system.

There was a strong element of direct democracy in Gaunkari since decisions of the general body could not be overruled by Managing Committee or by anyone else, once ratified. Filing of court cases by the Comunidade Attorney had to be backed by an extraordinary general body meeting. The Attorney however, was bound by law to intervene in any proceedings or challenge adverse orders before various authorities or courts on behalf of the Gaunkari. At the local level, the Government was vested in the assembly of one or two villages knows as Tarf, composed of the elders who represented each clan or vangor (Gune 1979: 14).

Though membership of Gaunkaris was largely inclusive of various castes, they did impose disabilities on lower castes by enrolling them at a late age into the community, by paying them lower dividends and by imposing disabilities in participation in community affairs. Gaunkari had three categories of members, i.e. the original members - Gaunkars, who received Zon (dividends) from land auctioned for cultivation, the Adventicios (intruders) who were admitted later, who included Zonkars, Accionistas and Saints and the officials who became members by manipulating their membership. They included Kulkarnis, Kulachars, and Vantels, who gained land rights and dividends by namus or namoxim (tenure) in lieu of their services, or paid an income called vanton.

12 The term Comunidades is a Portuguese usage for the Gaunkari system, essentially meaning a community. 
Memberships was largely hereditary, but could also be gained when certain communities passed resolutions to admit new members, when court so decreed or when persons purchased rights of the vangods ${ }^{13}$. There were only three exceptions to Gaunkars holding dual membership of communities. In some cases, Hindu Gaunkars, were ousted or left on their own from the Catholic majority Old Conquests due to religious persecution and these communities were reconstituted by Neo Christian Gaunkars. It is speculated that Zonkars secured perpetual and hereditary rights to the zon (dividend) in other communities for help rendered to them ${ }^{14}$ especially in repairing bunds $^{15}$ (Gomes Pereira 1981: 34), while Accionistas, became sharers (not shareholders), and acquired certain rights called dividus (not dividends) due to the conversion of interesses or interests ${ }^{16}$, in communities into freely alienable and inalienable shares or acções. The most interesting category of members, were the Saints, who were paid zon to pay for maintenance of churches, celebrate feasts and Holy Week services ${ }^{17}$ as Portuguese could not support the church due to its declining fortunes.

Communitarian nature of Gaunkaris is evidenced from the holding of land and assets in communion, which could not be alienated or demised in favour of any person or authority. These could not even be mortgaged or attached to settle debts, loss or deficit under the Code ${ }^{18}$. Social composition of Gaunkari effaced the belief that they were brahmanical (priestly caste) institutions. In the Old Conquests, besides exclusive one-caste Gaunkaris there were inter caste Gaunkaris sometimes including Brahmin and Shudras (untouchable) caste (Ibid.) as well.

In terms of religious composition, the Old Conquests Gaunkaris had a majority of Christian membership, while the New Conquest Communities were Hindu majority in c,omposition. The colonial state's intervention by way of conversion and privileging of Christians sowed the seeds of discord and destroyed the communitarian nature of the Gaunkari to some extent.

Functions of Gaunkaris mainly centered around cultivating fallow land and constructing irrigation systems, called "bands" (bunds) to make the land productive. Besides, Gaunkaris collected tax, effected welfare of Gaunkars and regulated life of the community as a whole.

In terms of autonomy from the colonial state, Gaunkaris originally contributed their own assets and resources to form Gaunkaris and hence were engaged with

13 The Vantels of Calangute (North Goa) became members by a resolution of the community of Calangute. The Naturais of Raia(South Goa) gained membersship through a Portuguese Court Decree, while the Daivadnya Brahmins (goldsmiths) of Aldona (North Goa) purchased rights to the vangods to gain membership. The latter became members through the late practice in the community of sale of rights of vangods by judicial auction.

${ }^{14}$ For instance the Gaunkars of Malar (North Goa) became Zonkars in Colvale Gaunkari (North Goa), for help rendered in the repairing of bunds.

${ }_{15}$ Bunds were mud barriers erected to prevent the saline river water from entering into the agricultural lands, to prevent damage to crops.

${ }^{16}$ According to André Pereira, a dedicated activist of rights of Gaunkari, the Accionistas were called upon to contribute money and in return they would get dividus which is not equivalent to dividends since they got a varying return from the Guankari depending on the income of the community (interview on 15th February 2007).

17 The services such as Mass and three day commemorations prior to Easter were all handed to the communities for funding.

${ }^{18}$ According to Article 647 of the Code of Comunidades. 
welfare of Gaunkars alone and were financially independent. The Portuguese colonial state, mistaking them for institutions of general welfare, forced them to defray the expenses of setting up primary schools, health services and emergency cells in cases of epidemics, for all the inhabitants. Later they were absolved of this burden and these activities, were then assigned to Municipalities, the funtas de Freguesia and the Provedoria ${ }^{19}$.

To assert its power over local communities the Portuguese state collected a fixed rent (tax) through a clerk, except in communities under Dessai (warrior caste). This tax was constant, irrespective of variations in income of Gaunkaris, except in case of war. Communities collected other taxes such as professional, commercial, industrial taxes as delegated by the Portuguese government. Though judicial powers, of the Gaunkaris are subject to debate, the Portuguese Decree of 1786, which discusses how to resolve the conflict between the judges of the Crown and those of the village communities, suggests that communities had judicial powers.

What were the linkages of the Gaunkaris with the state? Though the Code of Comunidades presumably has its origins in Indian jurisprudence dating back to the Hindu Vedic period (Pereira 2000: 6), it was codified within a colonial paradigm, by a Portuguese, Afonso Mexia. Inherent limitations of the codification were inability to comprehend the legal customs of the colonised and semantics of the local language and cultural context which made the code "far from being a comprehensive register of local customs and usages" (Pereira 1933).

One of the biggest blunders in the codification was the imposition of the continental feudal laws and Western concept of supremacy of the Sovereign over the land owned by the Comunidades, according to Andre Pereira (2000). Another blunder by the colonial and post-colonial government is the recognition of the Code as a Private $\operatorname{law}^{20}$. Since then the breach or violation of any of its rules or disputes came under the jurisdiction of the courts and finally the King, prior to Portuguese rule.

Under the colonial regime, these associative institutions were regulated by the state with a three fold strategy:

a) by making the Governor the sole arbiter, as head of state,

b) by appointment of an Administrador (Administrator) to oversee the functioning of the Comunidades and

c) by enacting periodic legislation to regulate tax collection, to oversee elections by appointing a thanadhar ${ }^{21}$, to prescribe inquiry procedures against fraudulent village officers; to ascribe power of inquiry into Gaunkari administration to "Judge of the Crown and King's revenue" (D'Souza 2000); to restrict expenditure by communities except in case of emergencies; to recruit all able bodied men, in case of war ${ }^{22}$; to abolish the posts of judges in Gaunkari and bring judicial cases under the colonial judiciary ${ }^{23}$; to codify functions and powers of Gaunkari, and

19 Provedoria is a Portuguese charitable organisation, which exists to this day and which now funds its activities from the money which accrues from its public lottery, approved by the State.

20 This was done vide Diploma Legislativo No 2070 dated 15 April 1961 by the then Central Government of Portugal, through the Governor of Goa.

21 This was done by the Charter of 1526 (applicable to Ilhas Taluka).

22 Through the Regiment of 1735 (applicable to Ilhas, Salcete and Bardez).

23 Through the Decree of 1836. 
functions of the government officials dealing with Gaunkari. Legislation also dealt with appeals to the Administrator, Governor or the provincial council ${ }^{24}$. Legislation was also enacted to develop vast properties for welfare of the population ${ }^{25}$ and simultaneously abolish Câmaras Agrárias de Goa and pass on their attributes to the administrator of Gaunkari, to give it a semblance of decentralising power as Albuquerque had intended (Ibid.: 119). Inspite of this, the Diploma Legislativo recognised the Code of Comunidades as Private Law, and their land as absolute non state private property. The Portuguese Government later abolished the Land Revenue wrongly levied on the Comunidades.

In the post-colonial period, the arbitration of all matters pertaining to Comunidades has been subject to the jurisdiction of courts. Under the British laws, now amended and in force in India and Goa, the lands and forests of the Comunidades are recognised as private property. After the abolition of the Right to Private Property as a Fundamental Right through 44th Amendment to the Indian Constitution, and its placement as Art 300-A as a statutory right, the state has the right to takeover private property and this cannot be challenged in the courts even with respect to the adequacy of compensation to be paid to property owners. This provided ideal legal legitimacy for unscrupulous governments right from the State government ${ }^{26}$ to the local governments ${ }^{27}$ to takeover Comunidade property in "public interest" and then allocate it for private purpose. The incumbent government has now moved legislation to have unrestricted access to Comunidade land $^{28}$.

Institutionalised Rural Local Power under the Post-Colonial State:

- Village Panchayats: The first ever democratic elections, after Goa's Liberation from Portuguese rule in 1961, based on universal adult franchise, were elections to the rural local government bodies called village panchayats ${ }^{29}$, held in $1962^{30}$.

${ }^{24}$ Through the Decree of 1886.

${ }_{25}$ Through the Code of 1905. The Code was reframed in 1933 and again in 1961.

${ }^{26}$ Ministers and bureaucrats have built houses or pushed illegal occupation of Comunidade land by non-Goans squatters and then enaced laws to legalise the same. The incumbent Congress Government's Information Technology minister has previously stated in a press briefing that all illegal occupation on Comunidade land would be legalised and no further encroachment will be allowed.

27 The case of Kundai panchayat, in Ponda Taluka where people forced all local village government (Panchayat) elected representatives to resign, since Comunidade land allocation by government for housing under a Government of India scheme for the poor was appropriated by the kin of the elected representatives, through a Panchayat committee resolution, in November 2006.

${ }^{28}$ On March 20 2006, a bill was introduced in the Goa Legislative Assembly to amend the Legislative Diploma No 2070 of 1961, to lease unrestricted land from the Comunidades without auction, for big government projects (Abreu 2006). This amendment has to be approved by the Comunidade body

29 The word panchayat goes back to ancient India, when community life was regulated by a panchayat, a body of five (in Hindi language panch means five) elders, who may have been representatives of clans and governed the village. The modern adoption of panchayats as institutions of Local Self Government was suggested by Mahatma Gandhi and the detailed three-tier system of panchayats was suggested by a committee appointed by the Federal Government called Balwantrai Mehta Committee, so named after the Chairman of the Committee.

${ }^{30}$ Elections were conducted under the Goa, Daman and Diu (Goa, Daman \& Diu) Village 
Although a three-tier system of Panchayati Raj (local government) was prevalent in India, as provided for under Art 40 of the Indian Constitution, the Goa model was simply a single tier system with village panchayats, at the village level and no panchayat samitis at the block or zilla parishads at the district level, due to small population.

The organisation of rural local government is thus, in 1962 there were a total of 180 villages panchayats (VPs) for Goa, and overland territories of Daman and Diu. After 2000, a two tier structure of local government was introduced, with 188 villages panchayats at village level and 2 Zilla panchayats at District level. ${ }^{31}$ The population of smallest to the biggest panchayats ranges from 1500 to above 8,000 people. All the 1,428 members of the panchayat are elected, with reservations (positive discriminations) for Other Backward Classes (OBCs), Scheduled Castes (SGs) and Scheduled Tribes $(\mathrm{STs})^{32}$ in proportion to their total population in that village panchayat, with the aim of empowering the underprivileged groups and bringing them into the political mainstream. There is no reservation for STs in Goa since their population is presently insignificant. Reservations for women exist for one third of the total seats in a village panchayat and for one third of the total offices of sarpanch (chairperson) and deputy sarpanch (deputy chairperson) by rotation. This has brought about cataclysmic changes in Indian democracy given the patriarchal structuration of society.

Tabl. III. - Composition of the village Pancharats in Goa

\begin{tabular}{lccccc}
\hline Districts & $\begin{array}{c}\text { Number of } \\
\text { Village } \\
\text { Panchayats }\end{array}$ & $\begin{array}{c}\text { Number } \\
\text { of }\end{array}$ & $\begin{array}{c}\text { Seats Reserved } \\
\text { Wor Women }\end{array}$ & $\begin{array}{c}\text { Seats Reserved } \\
\text { for SCs }\end{array}$ & $\begin{array}{c}\text { Seats Reserved } \\
\text { for OBCs }\end{array}$ \\
\hline North Goa & 119 & 875 & 284 & $2 \%$ of population & 31 \\
South Goa & 69 & 553 & 169 & $2 \%$ of population & 46 \\
Total & 188 & 1,428 & 453 & 51 & 77 \\
\hline
\end{tabular}

Panchayat Regulations (1962). Daman and Diu were then part of the erstwhile Union Territory of Goa and were bifurcated in 1987, when Goa attained Statehood.

${ }^{31}$ Goa is divided into two districts, North Goa and South Goa. Each district has a Zilla Parishad and each Zilla Parishad is divided into Blocks. In Goa, there are no elected local government bodies at the block level since states with population below 20 lakh can have only two governments - at district and village level. There are however government functionaries at block level for administrative purposes. The lowest level of local government is the Village Panchayat.

32 Reservation in Indian law prescribe a percentage of seats in to be reserved in local government, provincial and federal legislatures for communities that have been historically oppressed by other groups and underrepresented in these institutions. The Federal Legislature i.e. the Indian Parliament has enlisted these communities as Scheduled Castes, Scheduled Tribes and Other Backward Classes. Besides reservation of seats to legislatures, they also get reservations for recruitment to government jobs and now even for admissions to educational institutions. Reservations differ from affirmative action since the amount of concession to be made to underrepresented groups is at the discretion of the individual organizations, whereas the reservations are based on statutory quota prescribed by Indian Parliament. 
Depending on the demographic size of the panchayat, the number of elected members varies from five, seven, nine, to eleven members (based on populations between 1,500 and above 8,000 people). The elections to panchayats are held every 5 years and the reserved seats are rotated every 5 years.

The village panchayat is intended to be a community government free from political parties. It has an executive body of elected members as above and a people's assembly called Gram Sabha. The 73rd Amendment to the Indian Constitution has set aside 29 powers including powers to develop agriculture, minor irrigation, fisheries, rural housing, construction of roads, electricity, health, education, etc. The village panchayat is the only local body which can impose taxation and draws its revenue from taxes, duties, tolls and fees. All matters of planning, development and allocation of welfare schemes to citizens including the budget of the local government are to be discussed at the Gram Sabha.

- Zilla panchayats: The two Zilla panchayats (ZPs) - that of North Goa and South Goa, consist of 30 and 20 elected members respectively. Additionally, every Zilla panchayat includes three members of Indian Parliament elected from Goa; Members of the State/Provincial Legislative Assembly (other than ministers, Speaker or Deputy Speaker or Leader of Opposition); Chairperson of village panchayat in each taluka of the district elected from amongst themselves in the ratio of one such chairperson for a taluka having up to 15 panchayats and two such chairpersons for taluka having more than 15 panchayats who shall be a member of Zilla panchayat so long as he/she continues to be the sarpanch or chairperson of the panchayat.

Tabl. IV. - Composition of the Zilla Pancharats in GoA

\begin{tabular}{lcccccc}
\hline $\begin{array}{c}\text { Zilla } \\
\text { panchayats }\end{array}$ & $\begin{array}{c}\text { Elected } \\
\text { Rep }\end{array}$ & $\begin{array}{c}\text { Reserved } \\
\text { for women }\end{array}$ & MPs & MLAs & $\begin{array}{c}\text { Indirectly elected } \\
\text { from Sarpanchas }\end{array}$ & Total \\
\hline North Goa & 30 & 10 & 1 Lok Sabha & 6 & 11 & 58 \\
South Goa & 20 & 7 & $\begin{array}{l}\text { 1 Lok Sabha } \\
\text { 1 Rajya Sabha }\end{array}$ & 5 & 6 & 39 \\
Total & & & 3 & 11 & 17 & 98 \\
\hline
\end{tabular}

The term of the elected members of the village panchayats and Zilla panchayats is five years. One third of the total seats of the Zilla panchayats are reserved for women. No seats are reserved for SCs, STs or OBCs. One seat of chairperson and one seat of deputy chairperson of the Zilla panchayats are reserved for women in rotation.

Constitutionally, the Zilla panchayats have been assigned the same powers but they essentially perform the functions of district level planning and coordination of all these activities of the village panchayats. They do not have powers of taxation.

The Provincial Government of Goa over the last 13 years after the 73rd Amendment has shown its intransigence to devolve any powers to local governments, both to village and Zilla panchayats. Apart from constituting these institutions and holding elections every five years, it has not so much as empowered the villages as self-sustaining units of local governance, or introduced participatory plan- 
ning, or sensitized government officials to local needs or promoted accountability of elected officials. Due to the geographical smallness of the state of Goa, ministers and Ruling party and Opposition party Members of the Legislative Assembly fearing deconstruction of state government powers, almost conspiratorially, have displayed a complete lack of political will to devolve political, administrative and financial powers to panchayats. Goa has the notoriety of being among only 3 out of 28 states in India, who passed the conformity legislation - The Goa Panchayati Raj Act 1994, but has not devolved a single power to the local governments at the District and village level. These powers though listed in the 11 th Schedule of the Indian Constitution have to be allocated to local governments by the provincial governments through a notification by the Governor of the state ${ }^{33}$ in the Official Gazette.

The intransigence of the state government to devolve powers emerges from its desire to privilege itself above the local government by being patrimonial and patronising, in collaboration with the state bureaucracy. It puts no faith in the capabilities of rural communities to better understand and solve their problems, nor in their right to decide on issues and problems that confront or concern them (Fernandes 2003). While the State government has a 14 member cabinet, 64 departments and a mammoth bureaucracy of 50,000 which usurps Rs 250 crores by way of total emoluments each year (Narayan 1999), village panchayats have just one secretary (clerical official) and a peon and an average annual budget of around Rs 5 lakh.

Problems of democratization persist with the government unwilling to hold elections to the Zilla panchayats, in 1994 itself until they were held under Governor's Rule $^{34}$ in 1999, five years after panchayats were constituted. The State Election Commission (SEC), which is to be constituted mandatorily under the 73rd Amendment to conduct elections ${ }^{35}$ to urban and local government, was constituted in 1999. Secondly, the State appointed Second Election Commissioner has conspired with the provincial government to file a Public Interest Litigation (PIL) ${ }^{36}$, before the Court, in November 2006, to legitimise the provincial government's move to postpone the statutory village panchayats elections due in January 2007,

33 The Governor of a state/province is nominated by the Federal Government and is a nominal/titular head and acts on the advice of the elected Government within the framework of Parliamentary Democracy, unlike the Governor in United States who is directly elected.

34 Governor's or President's Rule can be imposed in a province in India when no party enjoys a majority in the provincial legislature or there is breakdown of law and order. In these circumstances, the Governor temporarily becomes the real head and exercise all the powers that are normally exercised by an elected government, till a new government is formed. His decisions have to be ratified by the new government.

35 Elections to the Indian Parliament and to State Legislatures are conducted by the Federal Election Commission. The 73rd Amendment to avoid government interference in local elections has constituted an independent State election commission to conduct elections to urban and rural local governments.

36 The PIL in the last decade or so has become a very effective instrument in the hands of citizens where they can approach the Courts to rectify instances of government apathy, bring before the Courts acts of corruption at very low cost of litigation. But in this instance it has been used by the government appointed functionary on behalf of the government itself. 
by stating that the voters' list has not been updated. The move is intended to delay the conduct of elections since the provincial/state government wishes to do hectic development activity prior to the State Legislature elections scheduled for May 2007, so that the coalition in power will gain some electoral mileage and have a good balance sheet to show prior to elections. Once Elections are announced, no development activity is permissible under the Indian Election Code.

As far as financial autonomy of local rural governments from the provincial government is concerned, the local governments are completely dependent on the provincial government. The State Finance Commission (SFG), which has to recommend distribution of finances between the state and local government, was constituted only in 1999, but its report was not accepted and the government continues to allocate finances to local government whimsically. The Second Finance Commission has been formed in 2006 but there is no hope that its report would be accepted either.

Planning powers at the village and district level have not been devolved to panchayats, zilla panchayat or the District Planning Committee which is supposed to coordinate planning between municipalities and panchayats to usher in participatory democracy. The entire process of decentralisation is stuck at various stages of redundancy as seen in Table $\mathrm{V}$ below:

\section{Tabl. V. - Time sGale of Devolution of powers to Panchayati Raj institutions in Goa}

\begin{tabular}{|c|c|c|c|}
\hline Tear & Event & Notable Features & Status in Fan. 2007 \\
\hline 1994 & $\begin{array}{l}\text { Goa Panchayat Raj } \\
\text { Act (GPRA) passed } \\
\text { by Goa Legislature }\end{array}$ & $\begin{array}{l}\text { - } 2 \text { tier structure proposed } \\
\text { - No elections held } \\
\text { - } 29 \text { powers listed in the Act }\end{array}$ & No powers devolved \\
\hline 1997 & $\begin{array}{l}\text { Village panchayat } \\
\text { elections held }\end{array}$ & $\begin{array}{l}\text { - } 188 \text { panchayats constituted } \\
\text { - No elections held for ZPs }\end{array}$ & $\begin{array}{l}\text { V.P. Elections last held in } \\
\text { Jan. 2002. Now due in } \\
\text { Jan. } 2007\end{array}$ \\
\hline 1999 & $\begin{array}{l}\text { State Finance } \\
\text { Commission (SFG) } \\
\text { constituted in } \\
\text { Feb. } 1999\end{array}$ & $\begin{array}{l}\text { - Chairman took office } \\
\text { in April } 1999 \\
\text { - Report submitted in } \\
\text { April } 1999\end{array}$ & $\begin{array}{l}\text { SFG recommendations } \\
\text { not implemented by } \\
\text { Goa Government }\end{array}$ \\
\hline 1999 & $\begin{array}{l}\text { State Election } \\
\text { Commission (SEG) } \\
\text { constituted }\end{array}$ & $\begin{array}{l}\text { - Constituted } 5 \text { years after } \\
\text { GPRA passed }\end{array}$ & $\begin{array}{l}\text { SEG conducted the } 2002 \\
\text { election for the first } \\
\text { time. }\end{array}$ \\
\hline 2000 & $\begin{array}{l}\text { Zilla Parishads (ZPs) } \\
\text { constituted }\end{array}$ & $\begin{array}{l}\text { - Elections held under } \\
\text { President's/Governors } \\
\text { Rule } \\
\text { - } 25 \text { subjects in the Act } \\
\text { - No powers devolved } \\
\text { - } 5 \text { minor subjects } \\
\text { delegated to ZPs from } \\
\text { 1999-2000 financial year } \\
\text { onwards }\end{array}$ & $\begin{array}{l}1 \text { minor subject taken } \\
\text { away from ZPs and } \\
\text { transferred to Parents } \\
\text { Teachers Association, } \\
\text { without consulting ZPs }\end{array}$ \\
\hline
\end{tabular}


Administrative decentralisation has not been forthcoming either. The 50 Zilla Parishad representatives have not devolved any of the 25 powers allocated to them under Schedule II of the Goa Panchayati Raj Act but continue to enjoy perks of office. Instead five functions (minor irrigation, farmers training, maintenance and repair of government primary schools, construction/repair and maintenance of rural roads, rural health centres and sub centres and water supply) were allocated to them, of which repair of government primary schools was taken back and given to private bodies - the Parent Teachers'Associations.

Deficiencies persist at the local government level also, where a kind of institutional inferiority complex persists vis-à-vis the state government, the former are unable to initiate any project without state funding and manpower ${ }^{37}$. Endemic instability within the ruling groups at panchayat level, poor quality of leadership and political culture which works through exclusion and selective mobilisation, especially at Gram Sabhas (people's assemblies) (Fernandes 1999) have been responsible for the below dismal performance of panchayat or local rural government. Finally without any powers, panchayat executive committee and the Gram Sabha both become "talking shops" or fora to settle either political or village quarrels. Citizens do not attend Gram Sabhas in large numbers. In fact, the average attendance is only about $3 \%$. This rises to about $16 \%$ when there is an important issue to be discussed. Secondly, even panchayat members cannot be held accountable for their actions within the present framework since the Gram Sabha is only a deliberative and not decision-making body. In essence since there is no "stake" involved in local rural governments, both village panchayats and Zilla panchayats are virtually ineffective as institutions of governance. Even at the all India level there are only about 50 success stories, some of which have been cited in World Bank case studies, from among 23,4676 panchayats.

\section{Institutionalised urban local power under the post-colonial state}

The Portuguese colonial system of municipal administration paradoxically continued within the democratic framework, for 7 years after the Liberation of Goa, after which a New Goa Municipal Act was enforced by the Provincial Legislature of Goa. The Structure of the Municipalities however remained unchanged with one municipality/urban government for each taluka.

\section{The municipalities}

Presently, there is a Corporation for the capital city of Panjim and 12 Municipal councils with varying number of 10 to 20 elected members. The municipalities themselves are grouped into $\mathrm{A}, \mathrm{B}$, and $\mathrm{C}$ categories depending on population in those talukas. The designated functions of municipalities have remained substantially unchanged from 1968, despite Federal Government attempt to empower urban governments through the 74th Amendment to Indian Constitution. Their functions include garbage collection, maintenance of municipal gardens, construction and maintenance of gutters, issuing of licenses for construction, regulating streets and

${ }^{37}$ For ample illustrations, see Fernandes 2000. 
open spaces, public safety, prevention of nuisance and spread of dangerous diseases, regulation of trade and occupations, collections of house tax, etc.

The 74th Amendment 1992 mandated the passing of conformity legislation by all states and devolution of 21 powers to them. Provisions for reservation of onethird seats for women and for posts of chairperson and deputy chairperson were made. The Goa Municipalities (Amendment) Act 1993 empowers municipalities to prepare plans for economic development and social justice and perform the functions and implement schemes entrusted to them relating to Schedule $\mathrm{X}$ of the Constitution. Successive state governments in Goa neither have devolved powers as given in Schedule X, nor devolved finances as recommended of the State Finance Commission but done ad hoc annual financial allocation, limiting their functions to routine and marginal activities.

The District Planning Committee which has to integrate the plans or urban and rural local governments (municipalities, Zilla panchayats and village panchayats) has been constituted, but dysfunctional. The Provincial government therefore retains all planning and decision making powers, since in a small state of Goa with 13 ministers, 1 Parliamentary Secretary ${ }^{38}, 10$ chairpersons of corporations, 40 Members of the Legislative Assembly (MLAs), there is no space left for empowered local governments and if local government were delegated substantive powers very little would be left for State Government to do (Nayak 2003).

Due to Federal Government welfare schemes, municipalities are able to undertake poverty alleviation schemes to impart training in skills, provide subsidies for self employment, and give monetary support to the girl child. The state government gives development grants, besides municipalities generate their own resources through tax and non tax revenues but these are inadequate even to meet establishment expenditure (salaries and maintenance of infrastructure). The highest amount of total funds/taxes received in the years 2000-2003 were by Margao Municipality in South Goa (Rs 341.15 lakhs - Euros 598,479), Corporation of the city of Panjim (Rs 303.19 lakhs - Euros 531,886) and Mapusa Municipality (Rs 250.59 lakhs - Euros 439,610). The provincial government does not want to make urban local governments financially independent since it has been quick to appropriate for itself remunerative taxes such as octroi (tax imposed on goods coming to the city), thus making municipal governments completely dependent on it (Ibid.).

Regretfully in Goa, due to the interference of political parties, especially the party in power at the provincial level, the municipalities, like the village panchayats, which are intended to be non partisan institutions under the Indian Constitution, are subject to intermittent instability, due to unseating of chairpersons and deputies. The provincial government wishes that the ruling group of the municipality should owe affiliation to it and if not then it would go all out to destabilise it to work the equation in its favour and install a group affiliated to its party. Use of money power is common in buying allegiance to the party in power at the provincial level. The municipality of Mormugao for instance had five instances where chairperson was removed through a no confidence motion and one resignation

${ }^{38}$ This post is equivalent to that of a Cabinet Minister and is usually given to a Ruling Party MLA. 
and three resignations of vice chairpersons, in the recent past. Unlike panchayats, where periodic elections have been held since 1962, the municipalities have been put under administrators, even as in the post 1993 period, where periodic elections at 5 years interval and continuous existence of municipalities is mandated.

Due to intermittent political interference in the urban governments by the ruling party at provincial level and failure to devolve financial and administrative powers, the performance of urban local governments has been to say the least poor. Goa is rated as the Number One tourist destination in India with more than $50 \%$ or its geographical area declared as urban in the 2001 Census. As the society becomes affluent and people from rural Goa move to cities and those from rest of India move here for jobs, to buy land and or set up industries, urban and rural governments are far from gearing up to the complex urban and rural problems that confront towns and cities of Goa. Impending problem areas include spatial planning, traffic management to cope with the increasing number of vehicles; pollution created by increasing industries and resorts, waste management, environment degradation as demand for land increases and energy, water and resource management.

The geographical smallness, the political culture of Goa and the power aspirations of the ruling class in the colonial and post-colonial periods have stunted the empowerment of local governments, both urban and rural. Though local governments themselves suffer from lack of legitimacy due to their own inadequacies, instability within the ruling groups and corruption, the refusal by the provincial government to empower and include them and the people in the planning process has resulted in a major public agitation against the Goa government's Regional Plan $2010^{39}$ in December 2006-January 2007, led by an educated middle class. People and NGOs vented their frustration by coming out on the streets and holding massive rallies in many parts of Goa to show their lack of faith in the government and called on the latter to revoke the Plan since they perceived that through large scale conversion of land from agricultural to residential and commercial purposes and its sale to non Goans and even foreign nationals, the ecology of Goa would be destroyed. People's power resulted in the government revoking the Plan on February 2007. Though this may be seen as reaction of people's power in a crisis situation, it had been simmering all along due to the refusal of provincial government to empower people through empowerment of local governments.

Besides the political culture cited above, societal make-up also reflects support, or lack of it, for local governments, modern and traditional. The pre-colonial society in Goa was characterised by a particular cohesiveness, which even shielded it from the colonial "onslaught" be it in terms of culture, language and institutional practices. "Networks of formal and informal sociability, charitable endeavours,

39 In India each provincial government has to make a perspective plan for allocation of forest, orchard, commercial and residential spaces which is called the Regional Plan. This plan in Goa was made by a Provincial Government appointed consulting firm without taking local bodes and people into confidence even as they have to be included in the planning process. 
participative membership among its adult population and social trust, defined as generalised willingness of individuals to trust their fellow beings" (Hall 1999) stands as a high point of associational involvement and therefore social capital within traditional associative institutions.

The post-colonial paradigm, though democratic in character, has actually not only damaged associative institutions through legislative interventions in "public interest" but also sabotaged federal government decentralisation and empowerment initiatives at the grassroots level. It is exigent that people, NGOs and community based organisations should participate in local government and demand statutory financial allocations and planning autonomy for local governments both municipalities and panchayat raj institutions, and create legitimacy for associative institutions, since direct democracy is possible in a city state such as Goa.

The "aggrandiser ${ }^{40}$ state", which is predatory and takes over powers constitutionally assigned to local governments and behaves patrimonialy inhibits participatory governance envisioned within the parameters of the 73rd and 74th amendments even as empowered local governments have made a substantive difference to the lives of people in the neighbouring Indian states of Kerala, Tamil Nadu, Karnataka and West Bengal. This is a critical juncture wherein the state generated panchayat raj initiatives from above (the political contract) can synergise with community legitimised institutions in a kind of a social contract. The synergy between traditional institutions such as Gaunkari and panchayats can be experimented with, since the former had vibrant people's participation but for these panchayats should become social and not political institutions with less and less interference from political parties and provincial governments. This social contract which would bring with it the traditional dynamics of participation and associationalism of people at large, due to the "stake" of empowerment, could certainly help in legitimising and revitalising the functioning of local governments in Goa, only if the provincial government empowers them by shedding its own power compulsions for the "greater good" of democracy.

February 2007

Aureliano FERNANDES

Goa University, Department of Political Science

\section{References}

Abreu, R., ed. 2006, “Comunidade land up for grabs!”, O Heraldo, Panaji, J.D. Fernandes Publications, 20 March: 1.

Boxer, G.R. 1980, Portuguese Indian in the Mid 17th century, New Delhi, Oxford University Press, $57 \mathrm{p}$.

DeSouza, T. 1979, Medieval Goa: A Socio-Economic History, New Delhi, Concept Publishing Co., $315 \mathrm{p}$.

D'Souza, G. 2000, “The Village Communities", in C. Borges, O.G. Pereira \& H. Stubb (eds), Goa \& Portugal: History and Development, New Delhi, Concept Publishing Coalition: 111-123.

Fernandes, A. 1999, "Reconnecting Sabha to Gram", in R.G. Choudhury \& S.P. Jain (eds), Strengthening Village Democracy, Hyderabad, National Institute of Rural Development: 179-196.

${ }^{40}$ The term "aggrandiser government" is my own coinage derived from the verb "to aggrandise". It has been used as an adjective with the very same meaning. 
2000, "Delivery Constraints within Panchayat Framework", Journal of Rural Development (Hyderabad, National Institute of Rural Development), XIX (2): 277-293.

2003, "Aggrandiser Government and Local Governance", Economic and Political Weekly (Mumbai, Krishna Raj), XXXVIII (27], July 5: 2873-2879.

Government of Goa 1994, The Goa Panchayati Raj Act (1994), Panaji, Government of Goa, First edition, $184 \mathrm{p}$.

Gomes, O. 2004, Goa, New Delhi, National Book Trust, 363 p.

Gune, V.T., ed. 1979, Gazetteer of Union Territory of Goa, Daman and Diu, Gazetteer Department, Panjim, Government of Union Territory of Goa Daman and Diu, 1023 p.

Hall, P.A. 1999, "Social Capital in Britain", British Fournal of Political Science (London, Blackwell Publishers), XXIX (3), July: pgs unavailable.

Narayan, R., ed. 1999, "Downsizing Government" (editorial), O Heraldo (Panaji, J.D. Fernandes Publications), 5 March: 6.

Nayak, R. 2003, The Politics of Urban Councils: Can instability promote development?, Paper presented at a State Seminar on Good Urban Governance, organised by Department of Political Science, Goa University.

Pereira, R., Gomes 1981, Gaunkari (The old village institutions), Panaji, Goa, Published by author, translated by M.J. Alvares, vol. II, 166 p.

Pereira, A.A. 2000, Comunidades of Goa, Panjim, S.H. DeSouza \& D'Sa. E. publishers, 15 p. Also available at <www.skybusiness.com/savida/goaComunidades.html>.

Pereira, A.F., 1933, Institute Organico das Comunidades, p. 85-112 as quoted in DeSouza T., 1979, above.

Web resources

<en.wikepedia/wiki/Afirmative_action\#note-Richardson>

<http://www.pnet.ids.ac.uk/guides/participation/localgov.htm $>$ 